\title{
Evaluation of Thermal Residual Stress after Firing for Porcelain/Alloy Veneer
}

\author{
Kenzo ASAOKA and Norihiko KUWAYAMA \\ Department of Dental Engineering, School of Dentistry, Tokushima University, 3-18-15 Kuramoto-cho, \\ Tokushima, 770 Japan
}

Received on June 8, 1984

\begin{abstract}
Thermal residual stress and deformation of porcelain/alloy restoration, which is a three-layered veneer plate model, were calculated by the theory of statically indeterminate beam and the finite element method. The factors that have the greatest effect on thermal residual stress in the veneer are coefficient of thermal expansion, modulus of elasticity and thickness of the layers. The relation between these factors and thermal residual stress after firing were studied. The effect of physical and mechanical properties of the intermediate oxide layers and the effect of firing two laminated porcelains on metal were examined from these calculating results.
\end{abstract}

Key Words: Porcelain/Alloy Restoration, Thermo-Mechanical Residual Stress, Mechanical Compatibility

\section{INTRODUCTION}

The practical dentist has been faced with the clinical problem of occasional failure of the porcelain/alloy system. It is, of course, not suggested that all porcelain/alloy failures are the result of inadequate materials or incompatible systems for fabrication. Coefficients of thermal expansion, thermal conductivity, design of porcelain/alloy system, and the nature and strength of the bond are all factors that influence the ability of the porcelain to resist fracture during clinical use of the restoration. ${ }^{1,2)}$ Numerous researchers ${ }^{2-6)}$ believe that retention is related to the formation of metal oxides. However, it is difficult to assess what type of oxides contribute to bond strength, and what kind of bonding agents are effective. Furthermore, no uniformly accepted method for determining bond strengths has evolved. A pull-through test, involving pushing or pulling a metal rod through a doughnut of porcelain vitrified to the rod, is universally made. ${ }^{7-9)}$ However, this method does not indicate the actual bonding strength between these materials considering its stress distribution on loading. ${ }^{10)}$

Phillips ${ }^{11)}$ introduced the concept of compatibility, that is, compressive stress set up during the cooling of the sintered porcelain veneer will also play a part in improving the bond strength. Ceramo-metallic systems are deliberately designed with a very small degree of thermal mismatch in order to leave the porcelain in a state of compression, because the compressive strength of porcelain is greater than its tensile strength.

Tesk et al. ${ }^{12)}$ studied using three-layered porcelain veneered split rings to measure the compatibility of these materials. Information on the states of residual stress in porcelain/alloy systems was collected from the theoretical and experimental studies on the change in gap of its model. 
The aim of this investigation is to clarify the states of thermal residual stress using a three-layered veneered plate model.

\section{MATERIALS AND METHODS}

\section{(1) Materials}

Alloys used for the construction of porcelain/metal restoration are classified roughly as noble metal alloys and base metal alloys. These alloys have thermal coefficients of expansion of about $12-15 \times 10^{-6} /{ }^{\circ} \mathrm{C}$. However, there are some remarkable differences in these physical properties; i.e., fusion range, thermal conductivity, specific gravity, hardness, ultimate tensile strength, and modulus of elasticity. The modulus of elasticity is the most remarkable influence on the thermal residual stress among these physical properties. That of the base metal alloys ranges from $180 \mathrm{GPa}$ to $260 \mathrm{GPa}$, while that of the noble metal alloys is generally lower, from $80 \mathrm{GPa}$ to $130 \mathrm{GPa}$. The modulus of elasticity in this calculation is then assumed to be $80 \mathrm{GPa}$ for the noble metal alloys and $200 \mathrm{GPa}$ for the base metal alloys. One of the most difficult problems is to scrutinize the modulus of elasticity for porcelain and to examine further the behaviours at various temperatures. Various modulus of elasticity were then employed for the theoretical calculations; for example, Nielsen et al. ${ }^{13)}$ used $68 \mathrm{GPa}$; Tuccillo et al. ${ }^{14)}, 82 \mathrm{GPa}$; Anusavice et al. ${ }^{9}$, 68 $\mathrm{GPa}$; and Tesk et al. ${ }^{12)}, 82.7 \mathrm{GPa}$. Porcelain has, of course, a lower modulus of elasticity at high temperatures than that measured at room temperature. The value in this calculation was then regarded as $60 \mathrm{GPa}$. Porcelain and metal were treated as a completely elastic body with no changes in their physical and mechanical properties. Internal stresses were calculated during cooling from $600^{\circ} \mathrm{C}$ to $20^{\circ} \mathrm{C}$.

(2) Statically indeterminate beam

Figure 1 shows a model of a laminated porcelain veneer. As the porcelain veneer

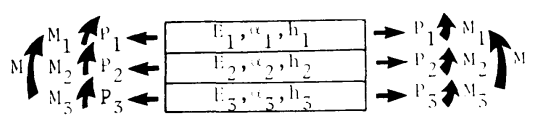

Figure 1 Schematic illustration of the analytical model.

was cooled to room temperature from the softening temperature of porcelain, internal stress is generated in each material because of different thermal shrinkages.

Table 1 List of symbols

\begin{tabular}{lll}
\hline E modulus of elasticity & subscript \\
$\mathrm{I}$ & moment of inertia of area & 1 material 1 \\
$\mathrm{M}$ & bending moment & 2 material 2 \\
$\rho$ radius of curvature & 3 material 3 \\
$\mathrm{b} \quad$ width & $\mathrm{m}$ metal \\
$\mathrm{h}$ thickness & $\mathrm{p}$ porcelain \\
$\alpha \quad$ coefficient of thermal expansion & $\mathrm{s}$ surface \\
$\mathrm{T}$ temperature & $\mathrm{i}$ interface \\
$\mathrm{P}$ load & $\mathrm{o}$ opaque porcelain \\
\hline
\end{tabular}




$$
\mathbf{P}_{1}+\mathrm{P}_{2}+\mathrm{P}_{3}=0
$$

These forces generate the moment in every material. As these materials adhere to each other, every plate should have the same radius of curvature. The sum of these moments is equal to those which result from the forces $P_{1}, P_{2}$ and $P_{3}$. Then,

$$
\begin{array}{ll} 
& \mathrm{P}_{1}\left(\mathrm{~h}_{2}+\mathrm{h}_{3}\right) / 2-\mathrm{P}_{2}\left(\mathrm{~h}_{1}-\mathrm{h}_{3}\right) / 2-\mathrm{P}_{3}\left(\mathrm{~h}_{1}+\mathrm{h}_{2}\right) / 2=\left(\mathrm{E}_{1} \mathrm{I}_{1}+\mathrm{E}_{2} \mathrm{I}_{2}+\mathrm{E}_{3} \mathrm{I}_{3}\right) / \rho \\
\text { where } & \mathrm{I}_{1}=\mathrm{bh}_{1}^{3} / 12 \quad \mathrm{I}_{2}=\mathrm{bh}_{2}^{3} / 12 \quad \mathrm{I}_{3}=\mathrm{bh}_{3}^{3} / 12
\end{array}
$$

Strain must be continuous at the interfaces. Thus,

$$
\begin{aligned}
& \alpha_{1} \mathrm{~T}+\mathrm{P}_{1} /\left(\mathrm{E}_{1} \mathrm{bh}_{1}\right)+\mathrm{h}_{1} /(2 \rho)=\alpha_{2} \mathrm{~T}+\mathrm{P}_{2} /\left(\mathrm{E}_{2} \mathrm{bh}_{2}\right)-\mathrm{h}_{2} /(2 \rho) \\
& \alpha_{2} \mathrm{~T}+\mathrm{P}_{2} /\left(\mathrm{E}_{2} \mathrm{bh}_{2}\right)+\mathrm{h}_{2} /(2 \rho)=\alpha_{3} \mathrm{~T}+\mathrm{P}_{3} /\left(\mathrm{E}_{3} \mathrm{bh}_{3}\right)-\mathrm{h}_{3} /(2 \rho)
\end{aligned}
$$

Stresses at the surface and at the interface of each material are calculated by Equations (1) to (4)

$$
\begin{aligned}
& \sigma_{1 \mathrm{~s}}=-\mathrm{E}_{1} \mathrm{~h}_{1} /(2 \rho)+\mathrm{P}_{1} /\left(\mathrm{h}_{1} \mathrm{~b}\right) \\
& \sigma_{12}=\mathrm{E}_{1} \mathrm{~h}_{1} /(2 \rho)+\mathrm{P}_{1} /\left(\mathrm{h}_{1} \mathrm{~b}\right) \\
& \sigma_{21}=-\mathrm{E}_{2} \mathrm{~h}_{2} /(2 \rho)+\mathrm{P}_{2} /\left(\mathrm{h}_{2} \mathrm{~b}\right) \\
& \sigma_{23}=\mathrm{E}_{2} \mathrm{~h}_{2} /(2 \rho)+\mathbf{P}_{2}\left(\mathrm{~h}_{2} \mathrm{~b}\right) \\
& \sigma_{32}=-\mathrm{E}_{3} \mathrm{~h}_{3} /(2 \rho)+\mathrm{P}_{3} /\left(\mathrm{h}_{3} \mathrm{~b}\right) \\
& \sigma_{3 \mathrm{~s}}=\mathrm{E}_{3} \mathrm{~h}_{3}(2 \rho)+\mathrm{P}_{3} /\left(\mathrm{h}_{3} \mathrm{~b}\right)
\end{aligned}
$$

The program using this calculation is shown in the Appendix.

(3) Finite element method

The finite element model of the porcelain/alloy veneer was constructed using square elements. The forces which were generated by the differences in thermal shrinkages, were added to the connecting points vector. ${ }^{15)}$ Figure 2 shows the normal stress distribution

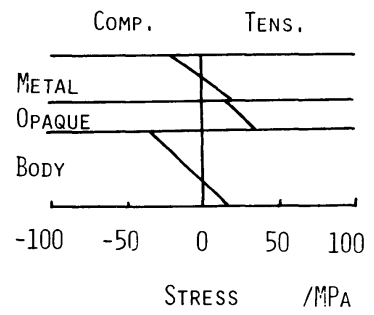

Figure 2 Normal stress distribution in the porcelain/alloy veneer.

Metal ; $\mathrm{E}_{\mathrm{m}}=80 \mathrm{GPa}, \mathrm{h}_{\mathrm{m}}=0.3, \alpha_{\mathrm{m}}=14 \times 10^{-6} /{ }^{\circ} \mathrm{C}$.

Opaque porcelain; $\mathrm{E}_{\mathrm{o}}=60 \mathrm{GPa}, \mathrm{h}_{\mathrm{o}}=0.2, \alpha_{\mathrm{o}}=14 \times 10^{-6}$

${ }^{\circ} \mathrm{C}$. Body porcelain; $\mathrm{E}_{\mathrm{p}}=60 \mathrm{GPa}, \mathrm{h}_{\mathrm{p}}=0.5, \alpha_{\mathrm{p}}=12 \times$ $10^{-6} /{ }^{\circ} \mathrm{C}$.

of the finite element solution, which was compared to the theoretical results of statically indeterminate beam. Good agreement was obtained.

\section{RESULTS AND DISCUSSION}

A. Effect of intermediate layer

Precious metal alloys used in porcelain/alloy restoration form oxide layers containing 
such elements as In and Sn. Base metal alloys form a thick oxide layer. If the oxide layer does not formed, wetting between porcelain and metal is poor. On the contrary, interface cracks often occur at the oxide layer. In both cases the intermediate layer plays a part in bonding. The relation between the sufficiently thin intermediate layer and thermal residual stress after firing was then studied.

1. Coefficient of thermal expansion

Figure 3 shows the relation between the coefficient of thermal expansion $\left(\alpha_{i}\right)$ of inter-

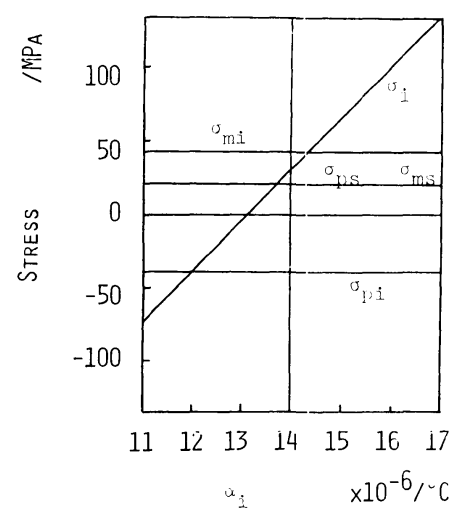

Figure 3 Relation between the residual stresses and the coefficient of thermal expansion of a sufficiently thin intermediate layer. Here, $\mathrm{E}_{\mathrm{m}}=80 \mathrm{GPa}, \mathrm{h}_{\mathrm{m}} / \mathrm{h}_{\mathrm{t}}=0.2, \alpha_{\mathrm{m}}=14 \times 10^{-6} /$ ${ }^{\circ} \mathrm{C}, \mathrm{E}_{\mathrm{p}}=60 \mathrm{GPa}, \mathrm{h}_{\mathrm{p}} / \mathrm{h}_{\mathrm{t}}=0.8, \alpha_{\mathrm{p}}=12 \times$ $10^{-6} /{ }^{\circ} \mathrm{C}$ and $\mathrm{E}_{\mathbf{i}}=60 \mathrm{GPa}$.

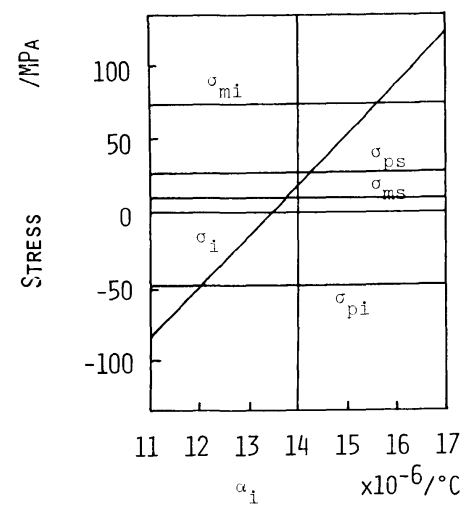

Figure 4 Relation between the residual stresses and the coefficient of thermal expansion of a sufficiently thin intermediate layer. Here. $\mathrm{E}_{\mathrm{m}}=200 \mathrm{GPa}, \mathrm{h}_{\mathrm{m}} / \mathrm{h}_{\mathrm{t}}=0.2, \quad \alpha_{\mathrm{m}}=14 \times$ $10^{-6} /{ }^{\circ} \mathrm{C}, \mathrm{E}_{\mathrm{p}}=60 \mathrm{GPa}, \mathrm{h}_{\mathrm{p}} / \mathrm{h}_{\mathrm{t}}=0.8, \alpha_{\mathrm{p}}=$ $12 \times 10^{-6} /{ }^{\circ} \mathrm{C}$ and $\mathrm{E}_{\mathrm{i}}=60 \mathrm{GPa}$.

mediate layer and residual stresses at the surfaces and interfaces. Moduli of elasticity of $E_{m}=80 \mathrm{GPa}, E_{p}=60 \mathrm{GPa}$ and $E_{i}=60 \mathrm{GPa}$; coefficients of thermal expansion of $\alpha_{m}$ $=14 \times 10^{-6} /{ }^{\circ} \mathrm{C}$ and $\alpha_{\mathrm{p}}=12 \times 10^{-6} /{ }^{\circ} \mathrm{C}$; and a metal thickness of $\mathrm{h}_{\mathrm{m}} / \mathrm{h}_{\mathrm{t}}=0.2$ were used for calculation. It is easy to obtain the stress distribution shown in Figure 2, that is, the normal stress distribution in the porcelain/alloy systems is drawn as a straight line from $\sigma_{\mathrm{ms}}$ to $\sigma_{\mathrm{mi}}$ in the metal and from $\sigma_{\mathrm{p}} \mathrm{i}$ to $\sigma_{\mathrm{ps}}$ in the porcelain for fixed $\alpha_{\mathrm{i}}$. The residual stress in the intermediate layer is directly influenced by the coefficient of thermal expansion of its layer. If $\alpha_{\mathrm{i}}$ represents values from $10.2 \times 10^{-6} /{ }^{\circ} \mathrm{C}$ to $14.3 \times 10^{-6} /{ }^{\circ} \mathrm{C}$, the residual stress in its layer is lower than the interfacial stresses in the metal and the porcelain. The strength of the intermediate layer is one of the most important factor for the porcelain/alloy systems. At the same time, an intermediate layer which is sufficiently thin must have a coefficient of thermal expansion between that of porcelain and that of alloy. Figure 4 shows the residual stress on the assumption of nonprecious bonding alloys, that is, $\mathrm{E}_{\mathrm{m}}=200 \mathrm{GPa}$ and the other physical and mechanical properties of alloy and porcelain assumed as in Figure 3. In this case, residual stresses at interfaces in the alloy and porcelain are higher than those of the case in precious metal alloys. It is therefore necessary for nonprecious alloy systems that the interfacial layer has good and strong bonding ability to the alloy and porcelain, and is sufficiently strong in itself. Porcelain/alloy veneer that comprises 
the metal with high modulus of elasticity, has smaller bending curvature after firing. Nonprecious alloy systems have then larger deformations that those of precious alloy systems. Curvature of bending is also determined from the states at the surface stresses of the veneer; i.e., $\sigma_{\mathrm{ms}}$ and $\sigma_{\mathrm{ps}}$.

2. Modulus of elasticity

Figures 5 and 6 show the changes of residual stress in the intermediate layer which is sufficiently thin. Figure 5 depicts the case for precious metal alloy systems, and Figure 6 , for the base metal alloy systems. If the intermediate layer has an coefficient of thermal expansion identical to that of metal, its tensile stress is maintained. In contrast, when

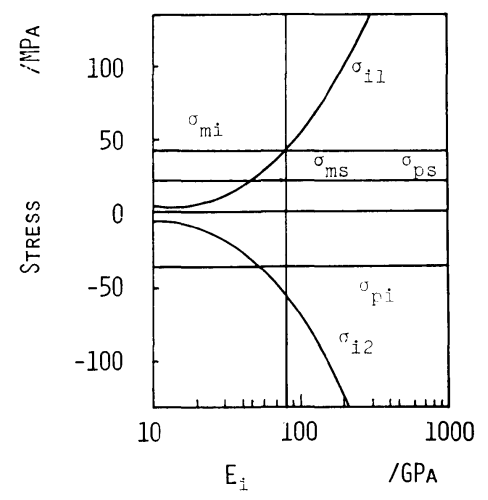

Figure 5 Relation between the residual stresses and the modulus of elasticity of a sufficiently thin intermediate layer. Two cases of the coefficient of thermal expansion of that layer are calculated. Case 1: $\alpha_{\mathrm{i} 1}=14 \times 10^{-6} /{ }^{\circ} \mathrm{C}$ and case $2: \alpha_{\mathrm{i} 2}=$ $12 \times 10^{-6} /{ }^{\circ} \mathrm{C}$. Here, $\mathrm{E}_{\mathrm{m}}=80 \mathrm{GPa}, \mathrm{h}_{\mathrm{m}} / \mathrm{h}_{\mathrm{t}}$ $=0.2, \alpha_{\mathrm{m}}=14 \times 10^{-6},{ }^{\circ} \mathrm{C}, \mathrm{E}_{\mathrm{p}}=60 \mathrm{GPa}$, $\mathrm{h}_{\mathrm{p}} / \mathrm{h}_{\mathbf{t}}=0.8$ and $\alpha_{\mathrm{p}}=12 \times 10^{-6} /{ }^{\circ} \mathrm{C}$.

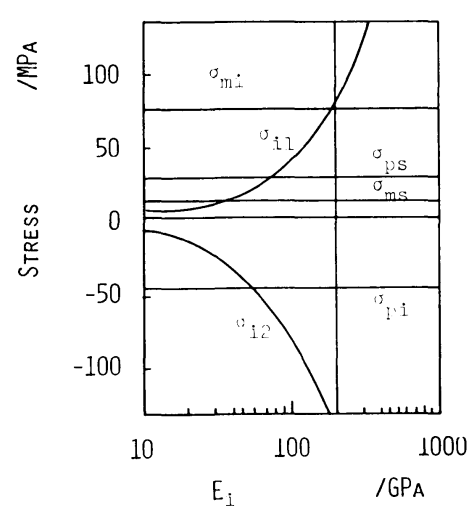

Figure 6 Relation between the residual stresses and the modulus of elasticity of a sufficiently thin intermediate layer. Two cases of the coefficient of thermal exx pansion of that layer are calculated. Case 1: $\alpha_{\mathrm{i} 1}=14 \times 10^{-6} /{ }^{\circ} \mathrm{C}$ and case 2 : $\alpha_{i 2}=12 \times 10^{-6} /{ }^{\circ} \mathrm{C}$., Here $\mathrm{E}_{\mathrm{m}}=200 \mathrm{GPa}$, $\mathrm{h}_{\mathrm{m}} / \mathrm{h}_{\mathrm{t}}=0.2, \alpha_{\mathrm{m}}=14 \times 10^{-6} /{ }^{\circ} \mathrm{C}, \mathrm{E}_{\mathrm{p}}=60$ $\mathrm{GPa}, \mathrm{h}_{\mathrm{p}} / \mathrm{h}_{\mathrm{t}}=0.8$ and $\alpha_{\mathrm{p}}=12 \times 10^{-6} /{ }^{\circ} \mathrm{C}$.

this coefficient is equal to that of porcelain, compressive stress is preserved. As the intermediate layer has higher modulus of elasticity $\left(\mathrm{E}_{\mathrm{i}}\right)$, the residual stress becomes higher. The materials used in porcelain/alloy systems must be chosen so as to form an intermediate layer with a low modulus of elasticity. Alloy has higher modulus of elasticity, thus, residual stress in the intermediate layer becomes high. For porcelain/alloy systems, the intermediate layer should have a lower modulus of elasticity than that of the alloy.

B. Effect of opaque porcelain

Porcelain used in porcelain/alloy systems is made from opaque porcelain and dentinenamel porcelain. Generally, each material has different coefficients of thermal expansion. When materials are carefully chosen, it is possible to have a low residual stress distribution in the veneer after firing. Furthermore, fracturing from surface cracks can be prevented.

1. Coefficient of thermal expansion

The relation between the residual stresses in the veneer after firing and the coefficient 


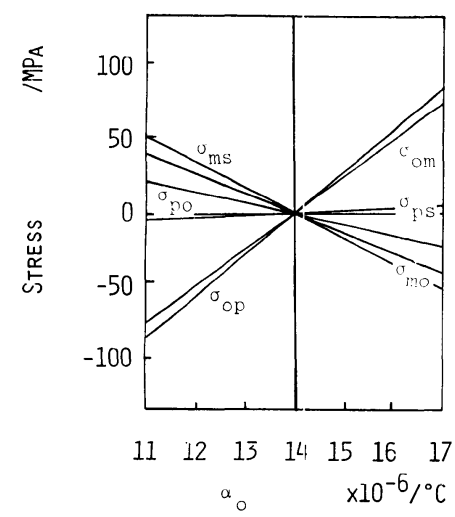

Figure 7 Relation between the residual stresses and the coefficient of thermal expansion of opaque porcelain. Here, $E_{m}=80$ $\mathrm{GPa}, \mathrm{h}_{\mathrm{m}}=0.2, \alpha_{\mathrm{m}}=14 \times 10^{-6} /{ }^{\circ} \mathrm{C}, \mathrm{E}_{\mathrm{p}}=$ $60 \mathrm{GPa}, \mathrm{h}_{\mathrm{p}}=0.6, \alpha_{\mathrm{p}}=14 \times 10^{-6} /{ }^{\circ} \mathrm{C}, \mathrm{E}_{\mathrm{o}}=$ $60 \mathrm{GPa}$ and $\mathrm{h}_{\mathrm{o}}=0.2$.

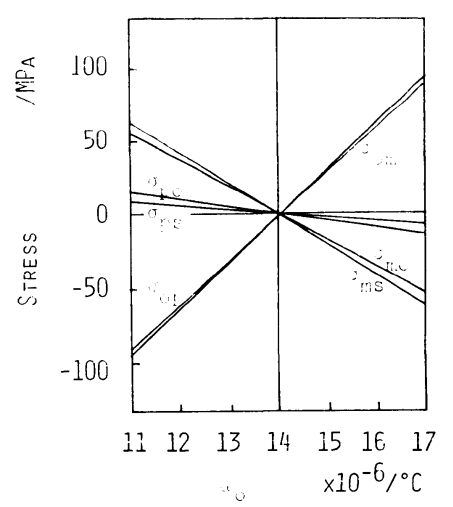

Figure 8 Relation between the residual stresses and the coefficient of thermal expansion of opaque porcelain. Here, $E_{m}=200$ $\mathrm{GPa}, \mathrm{h}_{\mathrm{m}}=0.2, \alpha_{\mathrm{m}}=14 \times 10^{-6} /{ }^{\circ} \mathrm{C}, \mathrm{E}_{\mathrm{p}}=$ $60 \mathrm{GPa}, \mathrm{h}_{\mathrm{p}}=0.6, \quad \alpha_{\mathrm{p}}=14 \times 10^{-6} /{ }^{\circ} \mathrm{C}$, $\mathrm{E}_{\mathrm{o}}=60 \mathrm{GPa}$ and $\mathrm{h}_{\mathrm{o}}=0.2$.

of thermal expansion $\left(\alpha_{0}\right)$ of opaque porcelain is shown in Figure 7 for precious alloy systems, and in Figure 8 for nonprecious alloy systems. Here, alloy has a coefficient of thermal expansion identical to that of dentin-enamel porcelain. The stress in the opaque porcelain is compression when the coefficient of thermal expansion of opaque porcelain is smaller than that of metel. In contrast, this value is larger than that of metal, thus, the stress becomes tension. The magnitude of the stress is proportional to the difference of these coefficients. If a metal has a higher modulus of elasticity, the residual stress becomes higher. If the stress in the opaque porcelain becomes compression, the stress in dentinenamel porcelain becomes tension

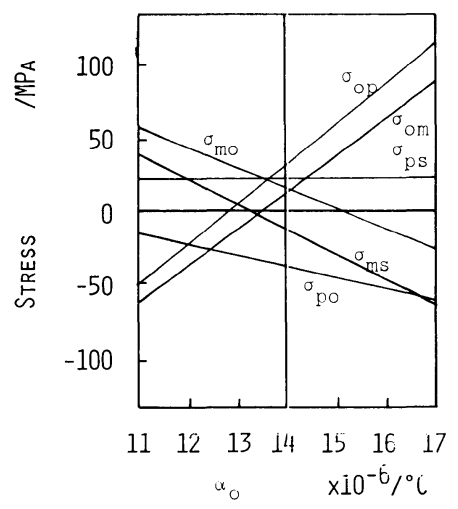

Figure 9 Relation between the residual stresses and the coefficient of thermal expansion of opaque porcelain. Here, $E_{m}=80$ $\mathrm{GPa}, \mathrm{h}_{\mathrm{m}}=0.2, \alpha_{\mathrm{m}}=14 \times 10^{-6} /{ }^{\circ} \mathrm{C}, \mathrm{E}_{\mathrm{p}}=$ $60 \mathrm{GPa}, \mathrm{h}_{\mathrm{p}}=0.6, \alpha_{\mathrm{p}}=12 \times 10^{-6} /{ }^{\circ} \mathrm{C}, \mathrm{E}_{\mathrm{o}}$ $=60 \mathrm{GPa}$ and $\mathrm{h}_{\mathrm{o}}=0.2$.

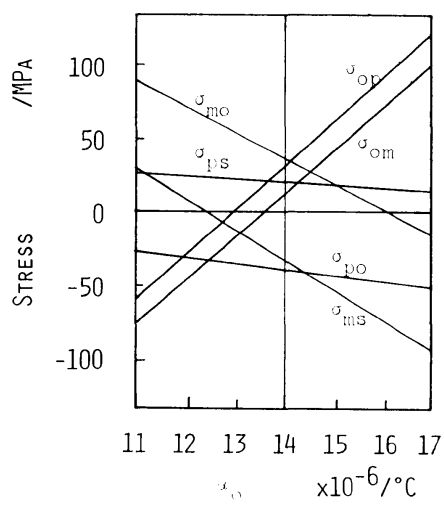

Figure 10 Relation between the residual stresses and the coefficient of thermal expansion of opaque porcelain. Here, $\mathrm{E}_{\mathrm{m}}=$ $200 \mathrm{GPa}, \mathrm{h}_{\mathrm{m}}=0.2, \alpha_{\mathrm{m}}=14 \times 10^{-6} /{ }^{\circ} \mathrm{C}$, $\mathrm{E}_{\mathrm{p}}=60 \mathrm{GPa}, \mathrm{h}_{\mathrm{p}}=0.6, \alpha_{\mathrm{p}}=12 \times 10^{-6} /$ ${ }^{\circ} \mathrm{C}, \mathrm{E}_{\mathrm{o}}=60 \mathrm{GPa}$ and $\mathrm{h}_{\mathrm{o}}=0.2$. 
In the case, the coefficient of thermal expansion of dentin-enamel porcelain is slightly lower than that of metal, stresses for precious alloy systems are given in Figure 9 and for nonprecious alloy systems in Figure 10. The changes in the coefficient of thermal expansion of opaque porcelain do not affect the stress at the surface of dentin-enamel porcelain. There is little difference between the stresses in the porcelain for precious alloy systems and those for nonprecious alloy systems. In this instance, the porcelain/alloy systems with the coefficient of thermal expansion for opaque porcelain between $12.0 \times 10^{-6} /{ }^{\circ} \mathrm{C}$ and 13.6 $\times 10^{-6} /{ }^{\circ} \mathrm{C}$ possess a wide low compressive stress part in the porcelain.

\section{Thickness}

The relation between the residual stresses and the thickness $\left(\mathrm{h}_{\mathrm{o}}\right)$ of opaque porcelain in precious alloy systems is shown in Figure 11. In this case, opaque porcelain has a coefficient of thermal expansion identical to that of the alloy and dentin-enamel porcelain has a coefficient lower than those of the other materials. At the interface between opaque porcelain and dentin-enamel porcelain, tensile stress remains on the opaque porcelain side and compressive stress on the dentin-enamel side. When thick opaque porcelain

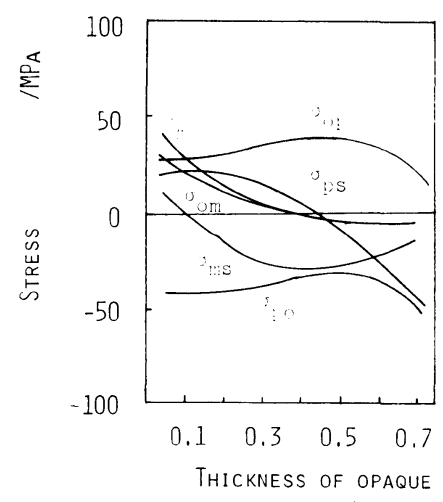

Figure 11 Relation between the residual stresses and the thickness of opaque porcelain. Here, $\mathrm{E}_{\mathrm{m}}=80$ $\mathrm{GPa}, \mathrm{h}_{\mathrm{m}} / \mathrm{h}_{\mathrm{t}}=0.2, \alpha_{m}=14 \times 10^{-6} /{ }^{\circ} \mathrm{C}, \mathrm{F}_{\mathrm{p}}=60$ $\mathrm{GPa}, \alpha_{p}=12 \times 10^{-6} /{ }^{\circ} \mathrm{C}, \mathrm{E}_{\mathrm{o}}=60 \mathrm{GPa}$ and $\alpha_{\mathrm{o}}=$ $14 \times 10^{-6} /{ }^{\circ} \mathrm{C}$.

is baked on the alloy, stress at the surface of dentin-enamel porcelain changes from tension to compression. The application of thick opaque porcelain to metal prevents surface cracks of dentin-enamel porcelain. However, interfacial stress between these porcelains causes high tensile stress on the opaque porcelain side in the veneer. Thus, careful attention is required at the interface between opaque porcelain and dentin-enamel porcelain during thermal cycles. The use of alloys with high moduli of elasticity increases residual stress, but the stress in the porcelain changes little.

\section{CONCLUSIONS}

The effect of physical and mechanical properties of the intermediate oxide layers and 
the effect of firing two laminated porcelains on metal were studied. The following conclusions were reached.

1. Interfacial oxide layers in nonprecious alloy systems require stronger bonding ability to the alloy and porcelain, and greater strength than needed in precious alloy systems.

2. In porcelain/alloy systems, the intermediate oxide layers should have a lower modulus of elasticity than that of the alloy.

3. The thermal expansion of opaque porcelain is an important physical property for the residual stresses in the porcelain/alloy systems.

4. Thick opaque porcelain on a metal makes the stress at the surface of dentin-enamel porcelain compression. Here, opaque porcelain has a coefficient of thermal expansion identical to that of the alloy, and dentin-enamel porcelain has a lower coefficient than those of the other materials.

5. In porcelain/alloy systems, porcelain should have a coefficient of thermal expansion slightly lower than that of the metal.

6. Nonprecious alloy systems have larger deformation after firing than precious alloy systems.

\section{REFERENCES}

1) Council on Dental Materials, Instruments and equipment: Porcelain-metal alloy compatibility: Criteria and test method. J. Am. Dent. Assoc., 102: 71-72, 1981.

2) Kelly, J.R., and Rose, T.C.: Nonprecious alloys for use in fixed prothodontics: A literature review, J. Prosthet. Dent., 49: 363-370, 1983.

3) Anusavice, K.J., Horner, J.A., and Fairhurst, C.W.: Advance controlling elements in ceramicmetal systems.-I. Precious alloys, J. Dent. Res., 56: 1045-1052, 1977.

4) Anusavice, K.J., Ringle, R.D., and Fairhurst, C.W.: Advance controlling elements in ceramicmetal systems.-II. Nonprecious alloys, J. Dent. Res., 56: 1053-1061, 1977.

5) Szantho von Radnoth, M., and Lautenschlager, E.P.: Metal surface changes during porcelain firing, J. Dent. Res., 48: 321-324, 1969.

6) Williams, T.R., Winghell, P.G., and Phillips, R.W.: Dental porcelain/Ni alloy interface reactions and their effective prevention. J. Dent. Res., 57: 583-591, 1978.

7) Shell, J.S., and Nielsen J.P.: Study of the bond between gold alloys and porcelain, J. Dent. Res., 41: 1424-1437, 1962.

8) Malhotra, M.L., and Maickel, L.B.: Shear bond strength of porcelain-fused-to-alloys of varying noble metal contents, J. Prosthet. Dent., 44: 405-412, 1980.

9) Anusavice, K.J., Dehoff, P.H. and Fairhurst, C.W.: Compressive evaluation of ceramic-meta! bond tests using finite element stress analysis, J. Dent. Res., 59: 608-613, 1980.

10) Asaoka, K. and Kuwayama, N.: Studies on the mechanical properties of a metal-ceramic restoration. -Estimation of the bond strength by pull out test, J. Jap. Soc. Dent. Appar. Mater., 21: 103108, 1980, (in Japanese)

11) Phillips, R.W.: Skinner's science of dental materials, 8th ed., W.B. Saunders Co., 1982, pp. 521-530.

12) Tesk, J.A., Himman, R.W., Widera, G.E.O., Holmes, A.D. and Cassel, J.M.: Effects of porcelain/ alloy interfacial diffusion zones on thermo-mechanical strain, J. Dent. Res., 62: 585-589, 1983.

13) Nielsen, J.P. and Tuccillo, J.J.: Calculation of interfacial stress in dental porcelain bonded to gold alloy substrate, J. Dent Res., 51: 1043-1047, 1972.

14) Tuccillo, J.J. and Nielsen, J.P.: Shear stress measurements at a dental porcelain-gold bond interface, J. Dent. Res., 51: 626-633, 1972.

15) Asaoka, K. and Kuwayama, N.: Studies on the mechanical properties of a metal-ceramic restoration. - Residual stress and deformation during cooling down, J. Jap. Soc. Dent. Mater. Dev., 1: 10-16, 1982, (in Japanese) 


\section{Appendix}

The computer program can be utilized to solve problems in this research.

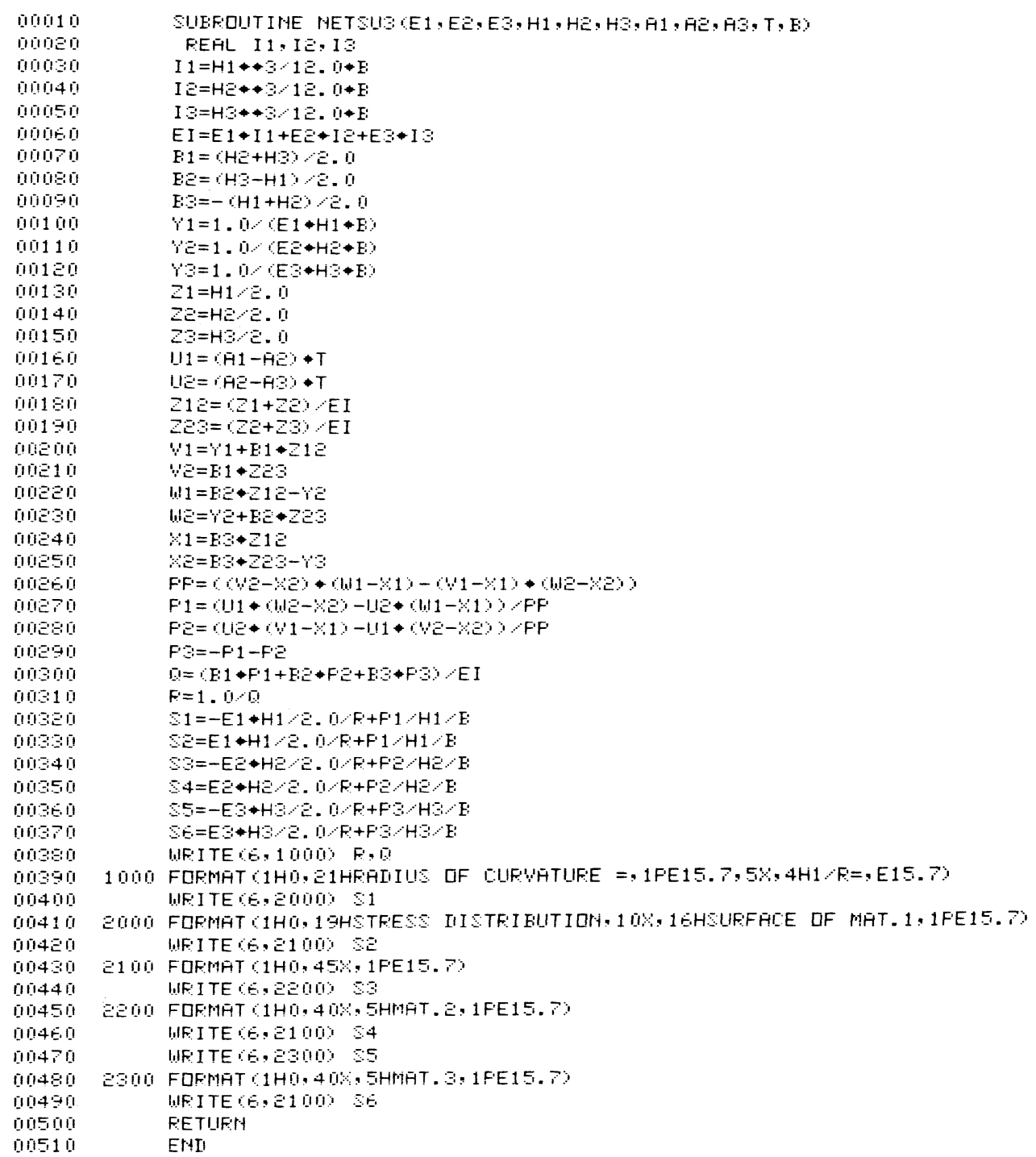




\title{
本号揭載論文の和文抄録
}

\author{
アルミ・ブロンズの腐食と変色 \\ 中山正彦*，J.B.モーザー**，F.H. グリーナー** \\ *日本菌科大学理工学教室 \\ **ノースウエスタン大学齒学部 (アメリカ)
}

アルミ・ブロンズ（銅・アルミニウム合金）は，工業 方面では海水耐食性を要求される部品などに用いられて おり，歯科においては，錆造用合金としてヨーロッパ， アメリカ合衆国, 南アメリカ,アジアなどで市販されて いる。それらを代表する組成として，工業用アルミ・ブ ロンズの中から，CDA $955(\mathrm{Cu}-\mathrm{Al}-\mathrm{Ni}-\mathrm{Fe})$ と CDA $956(\mathrm{Cu}-\mathrm{Al}-\mathrm{Si})$ をとりあげ, 電気化学的腐食挙動と変 色傾向を調べた。電気化学的腐食挙動の測定は, リンゲ ル液中と 10 分の 1 濃度のリンゲル液を用いて行ない，腐
食電位，腐食電流，腐食抵抗，ターフェル定数を得た。 これらの值や分極曲線は，合金間に大きな差は見られな かったが, 塩素イオン濃度の影響を大きく受けた。変色 試験は, Tuccillo and Nielsen の方法に従って $1 \%$ 硫化 ソーダ溶液中で行なった。変色の程度は, CDA 955 の 方が大きく，合金間の差は著しかった。CDA 956 は, 金合金, 銀・パラジウム合金よりは変色したが，ステン レス銅と同程度であり, CDA 955 は,アルファしんちゅ うやシリコン・ブロンズと同程度であった。

\section{金属焼付陶材の焼成後の残留応力について}

\section{浅岡憲三，桑山則彦}

\section{徳島大学歯学部蒾科理工学講座}

金属燒付陶材の機械的性質は構成各材料の 熱膨張 係 数, 熱仮導率, 機械的性質, 形状, 界面の接着強さによ り決まる。とくに，熱膨張係数と弾性係数は各材料の強 さと同椂に重要な因子である。

材料の適合性に関する問題を明らかにするために，3 層よりなる平板モデルを利用して金属焼付陶材の残留応 力と変形を梁の理論を適用して明らかにした。また，合

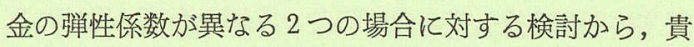
金属系合金拉よび非貴金属系合金を陶材焼付けに利用し
たときの残留応力，変形の違いについて調べた。その結 果, 焼成後の残留応力, 変形は非貴金属系合金の方が大 きくなるととがわかった。したがって，非貴金属系合金 では界面反応層が貴金属系合金よりあ金属焼付陶材の焼 成に際し重要な問題になる。とくに，その熱膨張係数と 弾性係数が重要であることがわかった。また，陶材の熱 膨張係数が金属の熱膨張係数よりも若干小さいととが適 合性の点から好ましいことが明らかにされた。

\section{焼付用陶材の諸物性と色彩 \\ 岡本佳三，堀部 隆 \\ 福岡崡科大学㧘科理工学講座}

焼付用陶村粉末の諸性質を調べるとともに，てれらの 観点から白金灯および赤外炬によって作製された陶材焼 成物の色調変化を客観的に測定したととろ，白金炉焼成 物之赤外炉焼成物との比較は, U-B 陶材の b 值のみ赤 外炉焼成物が $4.44(0.305)$ に対して $4.81(0.102)$ と高 く，他の測定值はすべて赤外炉焼成物の方が $L, a, b$ 值
において低值を示した。C 陶材の L, a, b 值は,すべて の測定において，低值であった。V-D 陶材の a 值と V-I 陶材の $\mathrm{b}$ 值が白金炉焼成物の-0.43(0.030) 亿対し $\tau,-0.32(0.041)$ と赤外炉焼成物が高值を示し, 他の 測定值はすべて赤外炉焼成物の方が低值を示した。J-O 陶材の $\mathrm{b}$ 值と J-B 陶材の L, b 值扔よび J-E 陶材の L 